9. Chebakova, Ye. A. (2019). Rol' myagkikh graficheskikh materialov $v$ protsesse povysheniya tvorcheskikh sposobnostey studentov. [The role of soft graphic materials in the process of increasing the creative abilities of students]. Tagil.

10. Shashkov, YU. P. (2006). Zhivopis' i yeyo sredstva. [Painting and its means]. Moscow.

\section{ВІДОМОСТІ ПРО АВТОРА}

ВОЛОШЕНКО Анна Вікторівна - аспірант кафедри образотворчого мистецтва Національного педагогічного університету імені М. П. Драгоманова.

DC 614.253.4-048.65:004=111

DOI: 10.36550/2415-7988-2021-1-192-161-166
Наукові інтереси: методика навчання образотворчого мистецтва у закладах вищої освіти, формування художніх умінь студентів в процесі оволодіння технікою пастель.

\section{INFORMATION ABOUT THE AUTHOR}

VOLOSHENKO Anna Viktorivna Postgraduate Student of the Department of Fine Artist,National Pedagogical Dragomanov University

Circle of scientific interests: methods of teaching fine arts at universities, formation of artistic skills of students in the process of mastering the technique of pastels.

Стаття надійшла до редакиіï 01.02.2021 p.

HABORETS Olha Andriivna -

Assistent Lecturer of Department of medical physics and information technologies № 2

Donetsk national medical university ORCID:https://orcid.org/0000-0001-7791-6795 e-mail: olga-gaborets@ukr.net

PYSHNOHUB Myroslava Volodymyrivna Lecturer of Department of Languages and Humanities №2 Donetsk national medical university

ORCID:https://orcid.org/0000-0003-1761-2831 e-mail: myroslavapyshnohub@gmail.com

\title{
THE FORMATION OF PROFESSIONAL COMPETENCE OF FUTURE PHYSICIANS BY MEANS OF INFORMATION TECHNOLOGY
}

Formulation and justification of the urgency of the problem. Nowadays, looking at current trends in education, society makes new requirements for the quality of professional training of students of medical specialties. The field of education in Ukraine needs well-trained professionals with the appropriate level of professional communication skills. In the process of studying at a higher educational institution, theoretical and practical knowledge of the essence and specifics of their future profession related to the need to solve problems of organizational and educational plan, students' subjective ideas about the main aspects of their further activity are formed. In process of studying, these ideas are transformed, reflecting the development of subjective vision opportunities to succeed in future independent work in the specialty.

Thus, the use of a competency-based approach in training is intended understanding by all subjects of the educational process of the ultimate goal of their activities: training a specialist who would have both key and special professional competencies, able to solve various problems during their professional activities, readiness for innovative activity, having a high motivational focus, understanding significance of their profession.

The traditional system of training cannot meet the requirements placed on us today. Increasing the level of professional competencies of students can be by using information and communication technologies during training. Because, ITs have an active impact on the learning and upbringing process of students since change the scheme of knowledge transfer and teaching methods. However, the introduction of IT in the system of education of medical students not only affects educational technologies, but and introduces new ones into the education process. They are related to the use of computers and telecommunications, special equipment, software and hardware, systems information processing.

Analysis of recent research and publications. The study of the competencybased approach is revealed in the works of V. Baidenko, A. Bermus, I. Zymna, V. Kozyrev, 
V. Kraevsky, O. Ovcharuk, O. Pometun, V. Strelnikov, A. Khutorsky. The analysis of psychological and pedagogical works testifies to the existence of different approaches to the definition of the concept of «professional competencies» and the ambiguity of the interpretation of the concept of «competence». Understanding basic issues between relationship of competence and competency, the development of requirements for competencies and their measurement is reflected in the works of foreign and domestic scientists (D. Raven, A. Khutorsky, N. Bibik, L. Vashchenko, I. Ermakov, O. Lokshina, O. Ovcharuk, L. Paraschenko, O. Pometun, O. Savchenko, S. Trubacheva). The problem of professional competency of future teachers was studied by L. Karpova, I. Parasyuk, G. Melnychenko, V. Demidova, L. Pashko, A. Onkovych and $\mathrm{V}$. Barkasi, the issue of professional training was studied by V. Lozovetska, the problem of competent economic workers was studied by V. Stasiuk and N. Zamkova. The issue of professional competency of future officers and its individual aspects have attracted the attention of many researchers. The works of O. Barabanshchikov, V. Bachevsky, A. Borisovsky, K. Verbytsky, V. Gerasymchuk, D. Ishchenko, T. Oliynyk, P. Onyschuk, G. Pyankovsky are dedicated to them. Components of the professional competency of a military specialist were found in the studies of A. Aronov (moral and politics), M. Bastrikov (management), A. Galimov (education), M. Zubaliya (physical), L. Chernyshov (military).

The analysis of scientific publications shows a significant interest of both foreign and domestic scientists in developing the problem of training future physicians, in particular the development of their professional competencies and the use of IT tools in preparation for work in the chosen specialty.

The theoretical-methodological and practical issues of the IT usage in vocational education of the physicians are featured in the works of P. Dev, V. Hryn, J. Lashof, P. Ozuah, N. Stuchynska, T. Sokolova, J. Ward.

The impact of IT on the development of professional competencies are investigated in detail in the works of O. Bilanov, N. Shygons1ka, A. Hutorskoy, S. Klepko, Ja. Nehaeva, Ju Bogachkov, A. Andreev, O. Lienkova. The works of the abovementioned scholars served as the background of this study.

The aim of the article is to reveal the increasing level of professional students' competencies by using information technologies during learning and to demonstrate their effectiveness while implementing in studying process.

The main material of the study. In our study, it is necessary to clarify the content of the concept of «professional competence of the future doctor». Analysis of the content of definitions of «competency» and «competence» leads us to understanding the essence of these concepts, which is important for building a model of a competent graduate of higher medical education, the formation of criteria for assessing student achievement, their readiness for future medical work. Under «competency» we will understand really formed knowledge, abilities and skills, and under «competence»person's ability in professional area of the doctor to applied the acquired competencies.

In foreign pedagogy, the concepts of «competence» and «competency» are identified. Thus, in the English-Ukrainian dictionary, English «competency (e)» corresponds to both competence and competency. Some scientists distinguish these concepts (G. Topolnytska, M. Yermolenko, V. Mizherikov), others - no (V. Afanasyev, M. Nagach, I. Vasiliev, A. Markova, O. Bodalov). The authors of the first approach emphasize that these concepts, although derived from the same root word «competency», have different meanings, different ways of being. V. Kraevsky and A. Khutorsky explain that competence translated from Latin «competentia» means a range of issues with which a person is well acquainted, knew them and has experience. A. Khutorsky [1] emphasizes that competence is a set of interrelated personality traits (knowledge, skills, abilities and methods of activity), which are assigned to the relevant range of subjects and processes and necessary for qualitatively productive actions in relation to them. Competency is a person's possession of the certain competence, which includes his personal attitude to the subject of activity. That is why, competence should be understood as a given requirement, the norm of educational training of the individual, and competency - as its really formed personal qualities and minimal experience. L. Fursova believes that the main difference between the concepts of «competence» and «competency» is that the first one is determined by the state, certain institutions or individuals who organize a particular activity, and the last one is acquired in the process of acquiring knowledge, skills, skills (competencies) and indicates the ability and inclination of the individual to perform a certain type of activity [2].

The authors of the second approach do not distinguish the relationship between the 
concepts of «competence» and «competency» and between their meaning and explain the use of these terms, primarily by the imperfection of translation (I.V. Rodygina). As «competence» is a concept that has entered the domestic educational theory and practice from the AngloSaxon educational tradition. Some authors insist on the priority of using the term "competency» over the term «competence», based on «domestic language stereotypes», and that the concept of «competence» is traditionally used to mean «range of powers», and «competency» associated with awareness, authority, qualifications, which are essentially pedagogical categories. Thus, many researchers, when translating foreign publications, automatically translate the word «competency» into Ukrainian / Russian as «competence» and vice versa. In our work, we will stick to the concept «competence» as the ability to apply acquired knowledge, skills and abilities necessary for the successful implementation of a certain highly productive activity in professional sphere.

The structure of professional medical students' competence includes cognitive, operational-practical and motivational criteria [4].

Indicators of the cognitive criterion of professional performance are evaluated with semantic indicators that determine the students received professionally-oriented knowledge of basic general-professional and professionaloriented (special) disciplines.

Operational-practical criterion includes the system of professional actions [5]:

- implementation of individual graphic and calculation works;

- problem solving;

- implementation of individual research tasks;

- implementation of modular works;

- successful internships.

Motivational criterion is manifested in the form of the necessary individual and personal qualities, motives and beliefs that organize and direct volitional efforts for quality implementation of professional activities. There are various approaches to determining the levels of professional competencies. Including the authors distinguish four levels: high, medium, sufficient and critical [4].

High level is characterized by the ability to ensure sustainable performance activities and show the unity of thoughts, feelings and actions in subjective characteristics. Students of this level are characterized by a high level of knowledge that forms such an operational thinking, in the structure of which they are organized and updated, able to put and solve creative tasks during professional activities. Students differ in manifestation initiative, independence, leadership and activity during learning activities, logical presentation of this knowledge with the analysis and generalization of educational material, understanding use of the received knowledge in practice. The medium level is characterized by the ability to provide relatively high productivity. Students are characterized by the presence of partial content knowledge, provided by the curriculum, poor knowledge of terminology, in case of logical presentation knowledge without analysis and generalization of educational material, partial understanding and use of knowledge in practice. This level is characterized by the coherence of opinions, feelings, behavior as a unity, but this consistency is quite inharmonious. Insufficient development of independence is shown in it. Cognitive activity is manifested in mastering scientific and methodological literature and IT with a focus on themselves. Majority of students are involved in partial self-education, guided by personal and professional motives.

Sufficient level is characterized by the ability to ensure productivity activities. This is realized at the level of the motivational sphere. Students have situational professional knowledge that has not yet acquired motivation, without analysis and generalization of training material limited. Make serious mistakes or do not perform quickly enough setting tasks, so practical skills are partially limited.

Critical level is characterized by the inability to ensure productivity activities. There is no cognitive activity in the field of professional activity, knowledge is fragmentary and lack of terminology knowledge, non-logical presentation of knowledge without analysis of educational material, the ability to work with educational material is poorly developed, lack of ability to objectively analyze the situation, there is emotional and moral underdevelopment. Students are passive in class, they have no motives for desires, aspirations, interests, or their uncertainty.

The boundaries of certain levels are variable. They reveal a number of contradictions, the main one is between the modern requirements for the professional level of the specialist and the actually achieved level that is driving force for the development of his professional competencies in today's higher education institution.

In order to confirm the calculated value of the similarity criterion, Pearson's criterion was used [5], by means of which it was found out: frequency of manifestation different values of the feature in the empirical and theoretical 
distributions or in two empirical distributions.

$$
\chi^{2}=\sum_{i=1}^{m} \frac{\left(n_{1 i}-n_{2 i}\right)^{2}}{n_{2 i}},
$$

where $m$ is the number of intervals into which the sample is divided, $n_{1 i}$ - number of members of the first sample, $n_{2 i}$ - number of members of the second sample.

The number of degrees of freedom $k$ is calculated by the formula:

$$
k=L-1 \text {, }
$$

where $L-$ number of intervals.

Based on an experimental study aimed at formation of professional competencies of students (in our case - students of medical university) by means of IT, two samples of distribution of students are received according to the levels of formation of their professional competencies. Let's calculate if the difference matters between the indicators obtained in the experimental and control groups before experiment and after it.

Circumstances force us to choose between two ways of action. For evaluation parameters by empirical laws hypotheses $H_{0}$ and $H_{1}$ are formulated.

$H_{0}$ : the samples are homogeneous, means the students included in it belong to one general summation. In other words, the difference between the level indicators was revealed the formation of professional competencies in the two study groups is insignificant. That is, for this feature can be considered the same.

$H_{1}$ : the samples are heterogeneous, means they are taken from different general summations: the difference between the levels of formation of students' professional competencies in the control and experimental groups is statically significant.

The probability of making the right decision of the hypothesis or abandoning it with probability $95 \%$ determine the level of significance $\mathrm{P}=0,05$ [5].

Table 1

Distribution of students of control and experimental groups to the beginning experiment on the levels of formation of professional competencies and calculation of the criterion homogeneity

\begin{tabular}{|l|l|l|l|}
\hline \multirow{4}{*}{ Level } & \multicolumn{2}{|l|}{$\begin{array}{l}\text { Number of students in } \\
\text { the group, \% }\end{array}$} & $\frac{\left(n_{1 i}-n_{2 i}\right)^{2}}{n_{2 i}}$ \\
\cline { 2 - 3 } & $\begin{array}{l}\text { Contro } \\
\text { Experimenta }\end{array}$ & \\
& 1 & 1 group, $n_{2 i}$ & \\
& group, & & \\
& $n_{1 i}$ & & \\
\hline
\end{tabular}

\begin{tabular}{|l|l|l|l|}
\hline High & 11,4 & 13,2 & 0,2 \\
\hline Medium & 34,9 & 34,3 & 0,0 \\
\hline $\begin{array}{l}\text { Sufficien } \\
\text { t }\end{array}$ & 25,5 & 20,2 & 1,4 \\
\hline Critical & 28,2 & 32,3 & 0,5 \\
\hline$\sum$ & 100 & 100 & 2,1 \\
\hline
\end{tabular}

Critical value $\chi^{2}$ where $k=3$, $a=0,05, \chi_{0,05}^{2}=7,81$.

Table 2

Distribution of students of control and experimental groups after experiment on the levels of formation of professional competencies and calculation of the criterion homogeneity

\begin{tabular}{|l|l|l|l|}
\hline \multirow{2}{*}{ Level } & \multicolumn{2}{|l|}{$\begin{array}{l}\text { Number of students in } \\
\text { the group, \% }\end{array}$} & $\frac{\left(n_{1 i}-n_{2 i}\right)^{2}}{n_{2 i}}$ \\
\cline { 2 - 3 } & $\begin{array}{l}\text { Contro } \\
\text { 1 group } \\
n_{1 i}\end{array}$ & $\begin{array}{l}\text { Experimenta } \\
\text { 1 group } \\
n_{2 i}\end{array}$ & \\
\hline High & 11,8 & 24,7 & 6,7 \\
\hline Medium & 45,3 & 47,8 & 0,1 \\
\hline $\begin{array}{l}\text { Sufficien } \\
\mathrm{t}\end{array}$ & 26,9 & 27,4 & 0,0 \\
\hline Critical & 16,9 & 0 & 16,9 \\
\hline$\sum$ & 100 & 100 & 23,7 \\
\hline
\end{tabular}

To check $H_{0}$ hypotheses calculate the actual value $\chi^{2}$ - criterion and compare it with the tabular value $\chi_{0,05}^{2}$. The sequence of calculations of actual value $\chi^{2}-$ the criterion is given in table 1 (before the experiment) and table 2 (after it). By formula (1) was determined that actual Pearson's criterion is:

before the experiment $\chi_{f a c i}^{2}=2,1$;

after the experiment $\chi_{\text {fac }}^{2}=23,7$.

For determination $\chi_{0,05}^{2}$ by the formula (2), calculate the number of degrees of freedom $k=4-1=3$.

Conclusions and prospects for further researches of directions. Professional competencies are a system of knowledge, skills and abilities, professionally significant personality traits that provide the ability to perform professional responsibilities of a certain level, and the components of professional competence are professional competencies, the main functions of which are: the formation of the ability to constantly learn and selfimprovement, representativeness, success, which, taken together, give the future specialists their competitiveness and competitiveness in the labor market.

Based on the analysis of literature sources 
[4], the basic criteria were formed professional competencies of future professionals in three areas:

1) by level of motivation, which manifests itself in the form of the necessary individual and personal qualities, motives and beliefs that organize and direct strong-willed efforts for quality implementation professional activity (motivational criterion);

2) by level obtained professionally directed knowledge, ideas about the features and conditions of professional activity are manifested in their completeness, depth and systematization (cognitive criterion);

3) by level formed professionally important skills and abilities to solve educational and professional tasks (operational and activity criterion).

At a critical value of $\chi^{2}$, if $k=3, a=0,05$, $\chi_{0,05}^{2}=7,81 \quad[6]$, comparing that before the experiment the actual value is less than the tabular value $\chi_{\text {fact }}^{2}<\chi_{0,05}^{2}(2,1<7,81)$ and proves that the null hypothesis is true. The level of manifestation of students' professional competencies in these groups are on the same level. After the experiment, vice versa: the actual value is more than tabular $\chi_{\text {fact }}^{2}>\chi_{0,05}^{2}$ $(23,7>7,81)$, means in this case it is necessary to accept alternative hypothesis. The obtained results allow us to conclude that the samples being compared can be considered inhomogeneous. We are convinced that there is a difference in the manifestation of professional competencies in students control and experimental groups, which proves the statistical significance of the difference in indicators of these groups obtained during the experiment.

The study revealed the levels of formation of professional competencies of medical students, physicians in particular. According to the results, the experimental group predominates medium and high levels. Analysis of the results obtained in the control group confirmed it has been suggested that the traditional system of training cannot satisfy those the demands placed on us today. The results of the experiment showed that when significance levels $\mathrm{P}=0.05$, the hypothesis of equality of the sample is rejected, means there is a significant difference between samples of control and experimental groups. This confirms our assumption about the possibility of increasing the level of professional competencies of students through the use information technologies during studying.

\section{СПИСОК ДЖЕРЕЛ}

1. Хуторской А. Ключевые компетенции как компонент личностно- ориентированного образования. Народное образование. 2003. №2. C. $58-64$.

2. Фурсова Л. Від літературної компетенції до життєвої компетентності // Українська мова література в середніх школах, гімназіях, ліцеях та колегіумах. 2005. №5. С. 12-21.

3. Родигіна I. Шляхи формування основних груп компетентностей учнів // Директор школи. 2004. №8. C. 148-153.

4. Коляда М. Г. Критерії оцінювання та рівні сформованості базових професійних компетенцій у майбутніх фахівців із інформаційної безпеки / М. Г. Коляда // Вісник післядипломної освіти. 2011. Вип. 4. С. 69-77. URL: http://nbuv.gov.ua/UJRN/Vpo_2011_4_11

5. Козак Л. В. Критерії готовності майбутніх викладачів дошкільної педагогіки і психології до інноваційної професійної діяльності / Л.В.Козак // Педагогічний процес: теорія і практика. 2013. Вип. 3. С. 76-88. URL: http://elibrary.kubg.edu.ua/3243/1/kozak.pdf.

6. Булах І. Є., Лях Ю. Є., Марценюк В. П., Хаїмзон І. І., Медична інформатика. К., ВСВ Медицина., 2017.

7. Габорець О. А. Критерії, показники та рівні готовності майбутніх лікарів засобами інформаційних технологій. URL: http://chasopys.ps.npu.kiev.ua/archive/662019/22/pdf.

\section{REFERENCES}

1. Khutorskaya, A. V. (2003). Klyuchevy'e kompetenczii kak komponent lichnostnoorientirovannogo obrazovaniya. [Key competencies as a component of a person-oriented education paradigm]. Moscow.

2. Fursova, L. (2005). Vid literaturnoyi kompetencziyi - do zhittyevoyi kompetentnosti. [From literary competency to life competence].

3. Rodygina, I. (2004). Shlyakhi formuvannya osnovnikh grup kompetentnostej uchniv. [Ways of forming the main groups of competencies of students]. Kiev.

4. Kolyada, M. (2011). Kriteriyi oczinyuvannya ta rivni sformovanosti bazovikh profesijnikh kompetenczij $u$ majbutnikh fakhivcziv iz informaczijnoyi bezpeki. [Cretiria for evaluation and formedness of the basic levels of professional competence in future professionals in information security].

5. Kozak, L. (2013). Kriteriyi gotovnosti majbutnikh vikladachiv doshkilnoyi pedagogiki $i$ psikhologiyi do innovaczijnoyi profesijnoyi diyalnosti. [Cretiria of readiness of future preschool pedagogy and psychology teachers for innovative professional activity].

6. Bulakh, I. Y. (2017). Medichna informatika. [Medical informatis]. Kyiv.

7. Haborets, O. A. (2019). Kriteriyi, pokazniki ta rivni gotovnosti majbutnikh likariv zasobami informaczijnikh tekhnologij. [Criteria, indicators and levels of readiness of future physician's by means of IT]. 


\section{ВІДОМОСТІ ПРО АВТОРІВА}

ГАБОРЕЦЬ Ольга Андріївна - асистент кафедри медичної фізики та інформаційних технологій №2 Донецького національного медичного університету.

Наукові нтереси: розвиток самовдосконалення майбутніх лікарів засобами інформаційних технологій.

ПИШНОГУБ Мирослава Володимирівна - викладач мовних та гуманітарних дисциплін №2 Донецького національного медичного університету.

Наукові інтереси: використання інформаційних технологій при вивченні мов, архетипологія поезії романтизму.
INFORMATION ABOUT THE AUTHOR

HABORETS Olha Andriivna - Assistent Lecturer of Department of Medical Physics and Information Technologies № 2, Donetsk national medical university.

Circles of scientific interests: development of future physicians' self-improvement by means of information technologies.

PYSHNOHUB Myroslava Volodymyrivna Lecturer of Department of Languages and Humanities №2, Donetsk national medical university, Ukraine.

Circles of scientific interests: use of information technology in language learning, archetypology of romantic poetry.

Стаття надійшла до редакиії 07.02.2021 р.

ГОНЧАРОВА Оксана Миколаївна аспірант кафедри іноземних мов та міжкультурної комунікації Харківського національного економічного університету імені Семена Кузнеця ORCID: http://orcid.org/0000-0002-1000-9670 e-mail: oksana.honcharova@hneu.net

\section{ПЕДАГОГІЧНА СИСТЕМА ФОРМУВАННЯ ПРОФЕСІЙНО-КОМУНІКАЦІЙНОӤ КОМПЕТЕНТНОСТІ ФАХІВЦІВ СФЕРИ ТУРИЗМУ}

\begin{abstract}
Постановка та обгрунтування актуальності проблеми. У нормативноправових документах, а саме закон України «Про вищу освіту» (2014) [1], національна доктрина розвитку освіти в Україні в XXI ст.
\end{abstract} [2] зазначається, що сучасні умови входження України в інформаційновисокотехнологічний простір, зростання комунікативності й інформаційної насиченості життя, інтеграції й глобалізації економіки, культури та соціальної сфери вимагають високого рівня комунікативної компетентності фахівців сфери туризму. Це зумовлює потребу в посиленні комунікативного складника професійної підготовки майбутніх фахівців указаного профілю, що передбачає модернізацію педагогічної системи формування професійно-комунікативної компетентності (цілей, принципів, змісту, методів та форм навчальної діяльності). Тож серед якостей випускника закладу вищої освіти (далі 3ВО), окреслених в освітньо-кваліфікаційній характеристиці бакалавра за напрямом підготовки «Туризм», виокремлено такі, як: здатність до ефективної взаємодії під час здійснення навчальної, професійної та іншої діяльності, навички дотримання етики ділового спілкування, вміння спілкуватися на високому культурному рівні державною та якнайменше однією з іноземних мов, чітко, й логічно висловлювати свої думки та переконання, здатність залежно від ситуації обирати найбільш відповідні засоби комунікації, демонструвати культуру мовлення, працювати в команді тощо.

Тож соціальне замовлення на підготовку компетентних фахівців сфери туризму зумовлюе необхідність створення педагогічної системи формування професійно-комунікативної компетентності фахівців туристичного профілю.

Аналіз останніх досліджень і публікацій. В розробках науковців розглянуто окремі аспекти педагогічної системи (О. Абдулліна, С. Белозерцев, І. Бех, Н. Волкова, І. Зязюн, З. Курлянд, Н. Ничкало, Н. Нікандров, В. Риндак, В. Сластьонін, Л. Соколова та ін.).

Теорію педагогічних систем у закладах освіти збагатили дослідження вчених: В. Беспалька, Т. Жижко, I. Каньковського, I. Краснощока, Н. Кузьміної, В. Прошкіна та iн.

Професійна туристична освіта, головним суб'єктом якої $є$ особистість майбутнього фахівця, розвинута для виконання професійних обов'язків, поступово займає вагоме місце в колі педагогічних досліджень. Серед них правомірно відзначити науковий 